
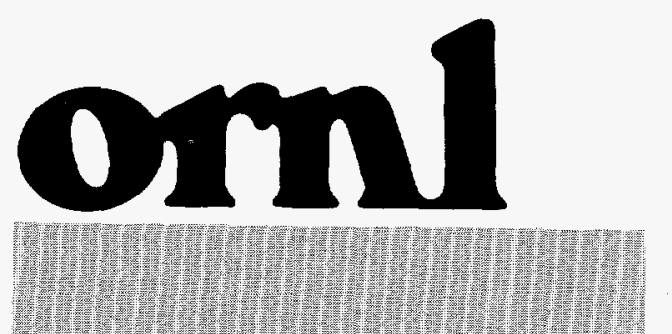

OAK RIDGE NATIONAL LABORATORY
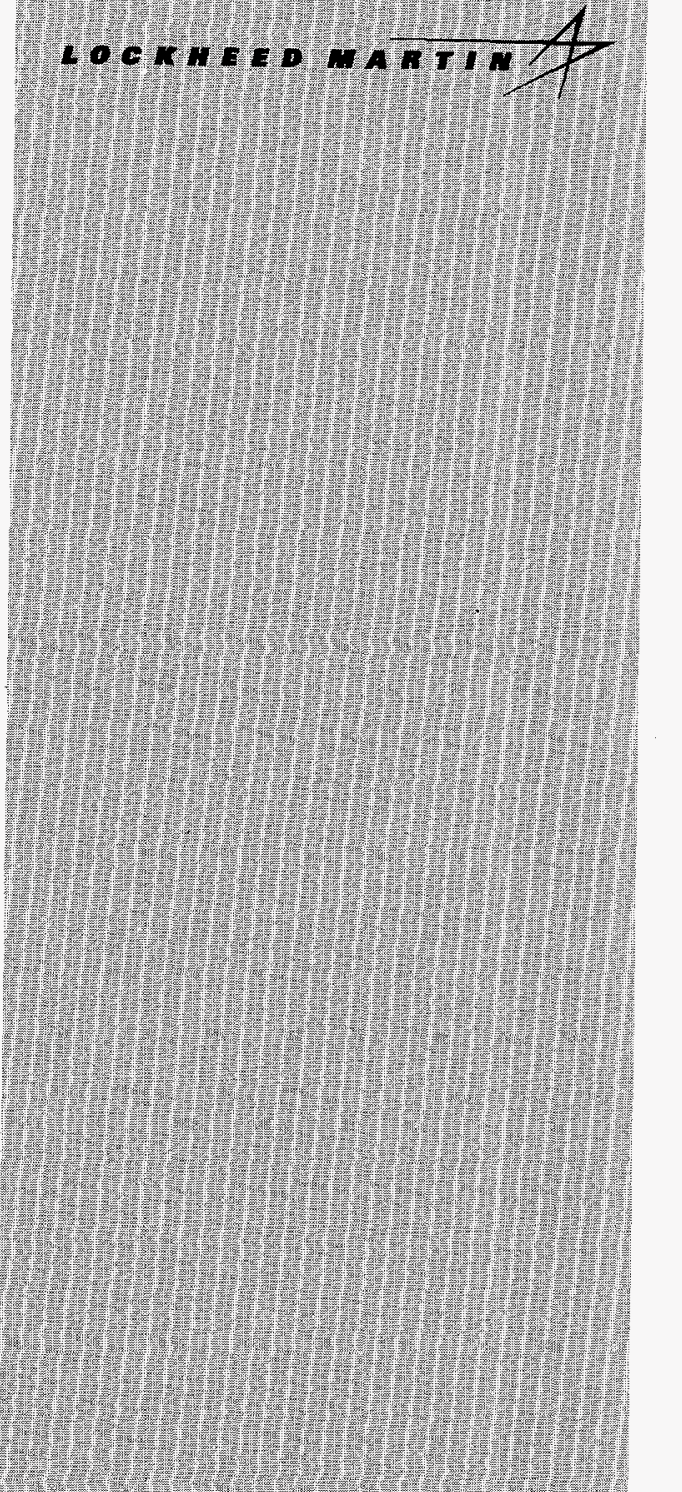

WANAGED ANO OPERATED BY LOCKHEED MARTN ENERGY RESEARCH CORPORATON FOR THE UNTED STATES DEPARTMENT OF ENERGY

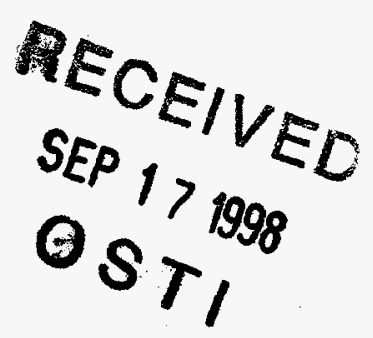

\title{
Caustic Leaching of High-Level Radioactive Tank Sludge: A Critical Literature Review
}

C. P. McGinnis

T. D. Welch

R. D. Hunt

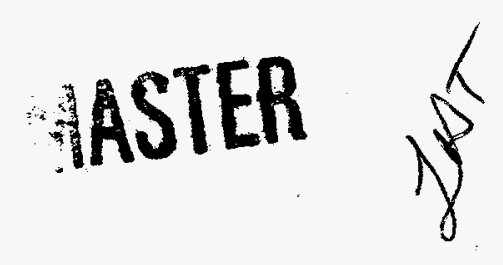


This report has been reproduced directly from the best available copy.

Available to DOE and DOE contractors from the Office of Scientific and Technical intormation, P.O. Box 62, Oak Ridge. TN 37831; prices available from (423) 576-8401, FTS 626-8401.

This report was prepared as an account of work sponsored by an agency of the United States Government. Neither the United States Government nor any agency thereof, nor any of their employees, makes any warranty, express or implied, or assumes any legal liability or responsibility for the accuracy, completeness, or usefulness of any information, apparatus, product, or process disclosed, or represents that its use would not infringe privately owned rights. Reference herein to any specific comınercial product, process, or service by trade name, trademark, manufacturer, or otherwise, does not necessarily constitute or imply its endorsement, recoinmendation, or favoring by the United States Government or any agency thereof. The views and opinions of authors expressed herein do not necessarily state or reflect those of the United States Government or any agency thereof. 


\section{DISCLAIMER}

Portions of this document may be illegible in electronic image products. Images are produced from the best available original document. 


\section{Chemical Technology Division}

CAUSTIC LEACHING OF HIGH-LEVEL RADIOACTIVE TANK SLUDGE: A CRITICAL LITERATURE REVIEW

C. P. McGinnis

T. D. Welch

R. D. Hunt

Date Published: August 1998

Prepared by

OAK RIDGE NATIONAL LABORATORY

Oak Ridge, Tennessee 37831-6285

managed by

LOCKHEED MARTIN ENERGY RESEARCH CORP.

for the

U.S. DEPARTMENT OF ENERGY

under contract DE-AC05-960R22464 


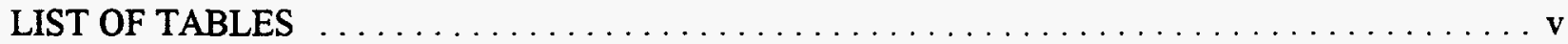

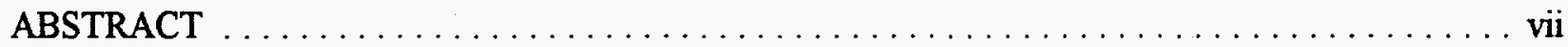

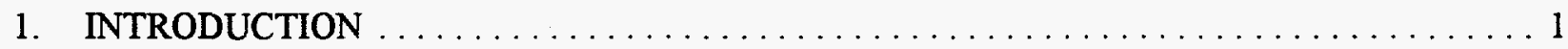

2. ANALYSIS OF EXPERIMENTAL RESULTS $\ldots \ldots \ldots \ldots \ldots \ldots \ldots \ldots \ldots \ldots \ldots \ldots \ldots \ldots \ldots$

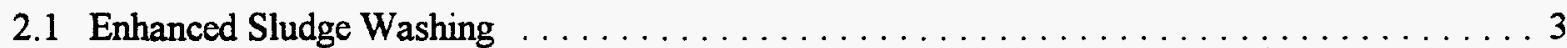

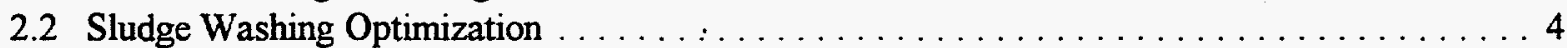

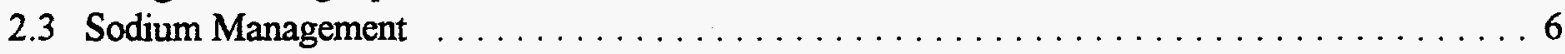

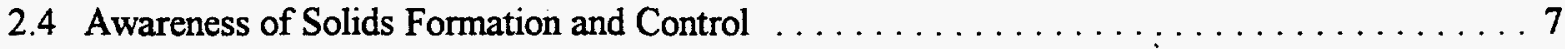

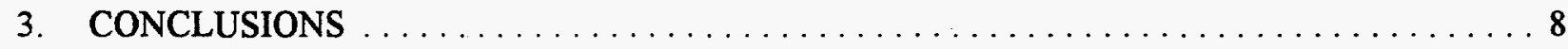

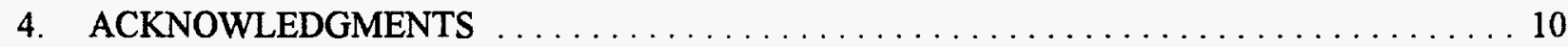

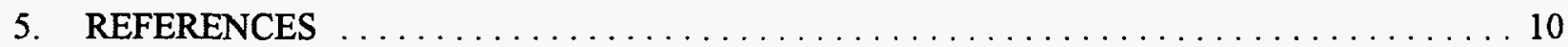





\section{LIST OF FIGURES}

Figure

1 Calculation of T-104 caustic leaching: $\mathrm{OH}^{-}$, initially $3 \mathrm{~m}$ at $75^{\circ} \mathrm{C}$; ambient temperature, $25^{\circ} \mathrm{C}$

2 Simplified diagram of enhanced sludge washing and the Bayer process 9

\section{LIST OF TABLES}

Table

1 Tank inventories (1995) and projected volume of glass canisters $\ldots \ldots \ldots \ldots \ldots \ldots \ldots$

2 Comparison of LLW and HLW management costs $\ldots \ldots \ldots \ldots \ldots \ldots \ldots \ldots \ldots \ldots$

3 Percentage removal of key elements by sludge washing $\ldots \ldots \ldots \ldots \ldots \ldots \ldots \ldots \ldots \ldots$

4 Amounts of water and sodium added during the ESW procedure $\ldots \ldots \ldots \ldots \ldots \ldots \ldots$

5 Current parametric studies for sludge leaching $\ldots \ldots \ldots \ldots \ldots \ldots \ldots \ldots \ldots \ldots \ldots$

6 Examples of effect of increasing $\mathrm{NaOH}$ concentration, solution/sludge ratio, leach time, and leach temperature on S-104 sludge dissolution

7 Effect of $\mathrm{NaOH}$ concentration on caustic leaching of $\mathrm{S}-104 \ldots \ldots \ldots \ldots \ldots \ldots \ldots \ldots \ldots \ldots \ldots$ 


\begin{abstract}
The Department of Energy (DOE) must treat and safely dispose of its radioactive tank contents, which can be separated into high-level waste (HLW) and low-level waste (LLW) fractions. Since the unit costs of treatment and disposal are much higher for HLW than for LLW, technologies to reduce the amount of HLW are being developed. A key process currently being studied to reduce the volume of HLW sludges is called enhanced sludge washing (ESW). This process removes, by water washes, soluble constituents such as sodium salts, and the washed sludge is then leached with $2-3 \mathrm{M} \mathrm{NaOH}$ at $60-100^{\circ} \mathrm{C}$ to remove nonradioactive metals such as aluminum. The remaining solids are considered to be HLW while the solutions are LLW after radionuclides such as ${ }^{137} \mathrm{Cs}$ have been removed. Results of bench-scale tests have shown that the ESW will probably remove the required amounts of inert constituents. While both experimental and theoretical results have shown that leaching efficiency increases as the time and temperature of the leach are increased, increases in the caustic concentration above 2-3M will only marginally improve the leach factors. However, these tests were not designed to validate the assumption that the caustic used in the ESW process will generate only a small increase $(10 \mathrm{Mkg})$ in the amount of LLW; instead, the test conditions were selected to maximize leaching in a short period and used more water and caustic than is planned during full-scale operations. Even though calculations indicate that the estimate for the amount of LLW generated by the ESW process appears to be reasonable, a detailed study of the amount of $L L W$ from the ESW process is still required. If the $L L W$ analysis indicates that sodium management is critical, then a more comprehensive evaluation of the clean salt process or caustic recycle would be needed. Finally, experimental and theoretical studies have clearly demonstrated the need for the control of solids formation during and after leaching.
\end{abstract}




\section{INTRODUCTION}

By the end of 1995 , the chemical reprocessing of spent reactor fuel and irradiated targets had generated a total of $215,300 \mathrm{~m}^{3}$ of solid high-level waste (HLW) and $158,100 \mathrm{~m}^{3}$ of liquid $\mathrm{HLW}$. The HLW, which is stored in underground tanks, contains the nonvolatile fission products, activation products, residual uranium, plutonium, and other transuranics (TRUs). After the HLW is more than a year old, the radioactivity comes primarily from ${ }^{137} \mathrm{Cs}$ in the liquids and ${ }^{90} \mathrm{Sr}$ in the solids. The relatively small amount of TRUs can be found in the solids. PUREX reprocessing of spent fuel produces an acidic liquid waste. At Hanford and the Savannah River Site (SRS), this HLW has been neutralized with sodium hydroxide, and sodium nitrite has also been added to prevent corrosion during storage in carbon-steel tanks. Neutralization of the HLW formed hydrated oxides, which precipitated and formed a sludge in the storage tanks. In cases where the neutralized supernatant liquids were concentrated sufficiently by evaporation, sodium nitrite and sodium nitrate crystallized to form salt cakes.

The Department of Energy (DOE) is required by law to treat and safely dispose of its radioactive tank wastes. It is expected that appropriate separation technologies will be used to divide the tank contents into HLW and LLW fractions. At Hanford, the pretreatment or separation steps are expected to generate $78,000,000 \mathrm{~kg}$ ( $78 \mathrm{Mkg}$ ) of LLW and $9.3 \mathrm{Mkg}$ of HLW. ${ }^{1}$ After these separation or pretreatment steps have been completed, the segregated waste will be immobilized and isolated geologically. After the HLW has been concentrated at Hanford and the SRS, it will be incorporated into borosilicate glass, which is acceptable for permanent disposal in a geologic repository. The LLW will be immobilized in grout or glass and stored on site. Table 1 lists the current volume of tank waste as well as the projected volume and number of HLW canisters. ${ }^{1}$

Table 1. Tank inventories (1995) and projected volume of glass canisters

\begin{tabular}{ccc}
\hline Volume of tank waste in $1995,1000 \mathrm{~m}^{3}$ & Hanford & SRS \\
Liquid & 89.839 & 58.700 \\
Solids & 143.668 & 67.800 \\
HLW volume after separations and vitrification & Hanford & SRS $^{b}$ \\
Projected cumulative volume of HLW glass & 14.277 & 3.720 \\
canisters, 1000 $\mathrm{m}^{3}$ & & \\
Estimated cumulative number of HLW canisters & 12,442 & 5,944 \\
\hline
\end{tabular}

${ }^{a}$ Based on assumptions in Reference 1 : canister has diameter of $0.61 \mathrm{~m}$ and is $4.50 \mathrm{~m}$ long (about $2 \mathrm{ft}$ in diam by about $15 \mathrm{ft}$ long). The nominal glass volume is $1.1 \mathrm{~m}^{3}$ with a minimum waste oxide loading of $25 \mathrm{vol} \%$ (excluding sodium and silicon).

${ }^{b}$ Based on assumptions in Reference 1: canisters are $0.6 \mathrm{~m}$ in diam by $3 \mathrm{~m}$ long (about $2 \mathrm{ft}$ in diam by about $10 \mathrm{ft}$ long). Each canister is assumed to contain $0.625 \mathrm{~m}^{3}$ of glass made with HLW from the reprocessing of spent nuclear fuel at SRS. The glass incorporates $36 \mathrm{wt} \%$ oxides from waste. 
Technology development efforts have focused on volume reductions of the HLW because the costs (per kilogram of waste oxide) of processing, immobilizing, and disposing of $\mathrm{HLW}$ are considerably higher than those for its LLW counterpart, as shown in Table 2. The primary incentives to reduce the total volume of $\mathrm{HLW}$ glass include a lower overall life-cycle cost and the limited availability of repository space. A process to reduce the volume of HLW should be cost effective if the amount of additional LLW generated is less than 33 times the amount of HLW volume reduction. From Table 2, a doubling of the pretreatment cost for HLW can be paid for with a $1 \%$ decrease in $\mathrm{HLW}$ volume (i.e., $\$ 28 / \$ 2126$ ).

HLW volume can be reduced by various means, such as loading as much waste into the glass as possible. Technology development efforts are isurrently under way to improve glass formulations so that maximum waste loadings can be achieved. However, modifications to the glass formulations are expected to be only partially effective. Another approach is to serparate the more abundant inert constituents, such as sodium and aluminum, from the radionuclides in the sludg,es. This process would also remove chromium, sulfate, and phosphate, which can cause vitrification problems. ${ }^{2}$ In 1993, the DOE considered three separation options for the Hanford sludges. The treatment options ${ }^{3}$ included simple sludge washing, enhanced sludge washing, and advanced separations. Simple sludge washing uses only water or dilute sodium hydroxide with corrosion inhibitors such as sodium nitrite. Enhanced sludge wrashing (ESW) refers to simple sludge washing that is followed by caustic leaching with $2-3 \mathrm{MNaOH}$ at an elevated temperature. The leached solids are then washed with dilute $\mathrm{NaOH}$ to remove the dissolved components and the added $\mathrm{NaOH}$. Advanced separations consist of complete dissolution, if possible, followed by extensive radionuclide separation.

Table 2. Comparison of LLW and HLW management costs

\begin{tabular}{|c|c|c|c|c|}
\hline & \multicolumn{2}{|c|}{ Hanford $^{a}$} & \multicolumn{2}{|c|}{ International Atomic Energy Agency $^{b}$} \\
\hline & $\begin{array}{l}\text { LL.W } \\
\text { (\$/kg } \\
\text { waste } \\
\text { oxide) }\end{array}$ & $\begin{array}{c}\text { HLW } \\
\text { (\$/kg } \\
\text { waste } \\
\text { oxide) }\end{array}$ & $\begin{array}{l}\text { LLW } \\
\left(\$ / \mathrm{m}^{3}\right)\end{array}$ & $\begin{array}{l}\text { HLW } \\
\left(\$ / \mathrm{m}^{3}\right)\end{array}$ \\
\hline Pretreatment & 16 & 28 & & \\
\hline Immobilization & 44 & 728 & & \\
\hline Disposal & 4 & 1,370 & $600-6,800$ & $450,000-1,400,000$ \\
\hline Total & 64 & 2,126 & & \\
\hline
\end{tabular}

An analysis of the options led to the conclusion that simple sludge washing would result in an unreasonably large volume of HI,W and that advanced separation would require extensive technology development and complex facilities. Therefore, ESW was selected as the baseline process for sludge pretreatment. Several assumptions, for example, the minimum wash and leach factors ${ }^{6}$ in Table 3, were made about the ESW process, and verification of these assumptions was required by the DOE. This paper discusses the results of these verification stadies as well as other processing issues such as solids formation after leaching. 
Table 3. Percentage removal of key elements by sludge washing ${ }^{a}$

\begin{tabular}{ccccccccc}
\hline & $\begin{array}{c}\text { Minimum } \\
\text { goal }\end{array}$ & \multicolumn{2}{c}{ Test results on a weighted basis (\%) } & & \multicolumn{2}{c}{$\begin{array}{c}\text { Overall wash } \\
\text { and leach factor }\end{array}$} \\
& $(\%)$ & Wash & Leach & Total & & 1996 & 1997 \\
\hline $\mathrm{Al}$ & 68 & 14 & 74 & 88 & 60 & 92 \\
$\mathrm{Cr}$ & 64 & 44 & 32 & 77 & & $40-65$ & 86 \\
$\mathrm{PO}_{4}{ }^{3-}$ & 74 & 55 & 35 & 90 & & 70 & 95 \\
\hline
\end{tabular}

${ }^{a}$ Reference 6.

\section{ANALYSIS OF EXPERIMENTAL RESULTS}

\subsection{Enhanced Sludge Washing}

As part of the verification studies, ESW studies ${ }^{7-16}$ have been performed on sludge samples from 34 Hanford tanks by researchers at Pacific Northwest National Laboratory (PNNL), Los Alamos National Laboratory (LANL), and Oak Ridge National Laboratory (ORNL). In the ESW study at ORNL, multiple tests were performed on sludge samples from a few Hanford tanks to evaluate the effects of temperature, leaching time, and caustic concentration. In contrast, the PNNL and LANL researchers have tested numerous sludge samples under a single set of conditions, which were periodically modified as new results were obtained. While the ESW concept appears to be relatively simple, the ESW test procedure is quite complicated. In 1995, the ESW procedure consisted of 18 steps. ${ }^{10}$ It should be noted that a small portion of each sludge sample undergoes extensive water washing without caustic leaching and that the remainder of the sample is only slightly washed before being subjected to the caustic leach tests. Therefore, none of the samples were subjected to the entire ESW process.

While the PNNL and LANL procedures, as well as the ORNL tests, were quite reasonable for bench-scale experiments, they were not designed to mimic the expected full-scale operations. For example, the researchers used excessive amounts of water and caustic, as shown in Table 4. Theoretical calculations based on phase equilibriums ${ }^{17}$ have determined the minimum volumes of water and caustic that must be used to remove the soluble salts and key nonradioactive metals from sludge in Hanford tank S-101. In the test with real waste, ${ }^{13}$ the volumes of water and caustic were seven and five times larger than required by the calculations, respectively; these excessive liquid volumes permitted much shorter wash $(0.5-1 \mathrm{~h})$ and leaching $(5 \mathrm{~h})$ times. During large-scale operations, the additions of water and sodium should be kept to a minimum so that a reasonable amount of LLW will be generated, and the wash and leaching times can be expected to be longer than those used in the laboratory tests. It is also important to remember that the sludge samples that were leached were not washed extensively first. Note in Table 4 the large increase in the cumulative wash and leach factors from 1996 to 1997 , even though only 8 of the 34 tanks were tested in $1997 .^{13,16}$ It is possible that additional ESW tests on other tanks in 1998 can change these factors further. While results of past bench-scale experiments have demonstrated that the ESW will probably exceed the minimum goals for removing key constituents, as shown in Table 3, the tests have not established that the ESW can meet the removal goals and generate an acceptable amount of LLW. It is unwise to draw conclusions about the contents of an entire tank based on a single test with a few grams of sludge. 
Table 4. Amounts of water and sodium added during the ESW procedure

\begin{tabular}{|c|c|c|c|c|c|c|}
\hline Tank & $\begin{array}{l}\text { Wet } \\
\text { sludge } \\
(\mathrm{g})\end{array}$ & $\begin{array}{c}\text { Dried } \\
\text { sludge } \\
\text { (g) }\end{array}$ & $\begin{array}{l}\text { Water } \\
\text { added, } \\
\text { initial wash } \\
\text { (mL/g } \\
\text { dried } \\
\text { sludge) }\end{array}$ & $\begin{array}{l}\text { Water } \\
\text { added, } \\
\text { last wash } \\
\text { (mL/g } \\
\text { dried } \\
\text { sludge) }\end{array}$ & $\begin{array}{c}\text { Sodium } \\
\text { added (g } \\
\mathrm{Na} / \mathrm{g} \text { dried } \\
\text { sludge) }\end{array}$ & $\begin{array}{c}\text { Initial } \\
\text { sodium (g } \\
\mathrm{Na} / \mathrm{g} \text { dried } \\
\text { sludge) }\end{array}$ \\
\hline B-106 ${ }^{a}$ & 8.80 & 3.53 & 55 & 11 & 1.70 & 0.49 \\
\hline $\mathrm{BX}-103^{a}$ & 7.41 & 5.24 & 29 & 41 & 3.61 & 0.11 \\
\hline BY $-110^{b}$ & 6.23 & 4.01 & 28 & 7 & 0.98 & 0.46 \\
\hline$C-104^{a}$ & 9.17 & 4.22 & 45 & 32 & 4.17 & 0.37 \\
\hline$C-105^{a}$ & 2.97 & 2.58 & 22 & 45 & 3.98 & 0.0061 \\
\hline S $-107^{b}$ & 5.71 & 3.40 & 32 & 33 & 4.28 & 0.26 \\
\hline$S X-108^{b}$ & 21.06 & 20.22 & 21 & 22 & 1.13 & 0.24 \\
\hline$S X-113^{a}$ & 3.25 & 1.63 & 39 & 51 & 6.50 & 0.034 \\
\hline S-104 & 5.14 & 4.85 & 18 & 31 & 2.16 & 0.019 \\
\hline $\mathrm{S}-101^{c}$ & 6.27 & 4.00 & 45 & 18 & 2.35 & 0.28 \\
\hline $\mathrm{S}-101^{d}$ & 10.0 & 6.4 & 4.7 & 7.1 & 0.32 & 0.28 \\
\hline
\end{tabular}

${ }^{a}$ Reference 16.

${ }^{b}$ Reference 11 .

${ }^{c}$ Reference 13

${ }^{d}$ Based on theoretical calculations using equilibrium constants (Reference 17).

\subsection{Sludge Washing Optimization}

Several DOE researchers are currently performing parametric studies on ESW to optimize the process for particular sludges and to provids: a much more reasonable estimate of the LLW that will be generated by the washes and leaches. During these studies, the effects of process variables such as $\mathrm{NaOH}$ concentration, temperature, and leaching time on the efficacy of the caustic leaching process will be determined. The test conditions for these parametric studies are shown in Table 5. The goal of these tasks is to minimize the overall system cost by optimizing the leaching of the $H L W$ to produce the appropriate amounts of wastes. As a starting point, researchers are using the aluminum concentration in the sludge to determine the solid/liquid ratio. 
Table 5. Current parametric studies for sludge leaching

\begin{tabular}{cc}
\hline Parameter & Proposed test points \\
\hline Caustic concentration, $M$ & 1,3 \\
Temperature, ${ }^{\circ} \mathrm{C}$ & $60,80,100$ \\
Leaching time, $\mathrm{h}$ & $5,24,72,168$ \\
\hline
\end{tabular}

Table 6 shows the effect of leach behavior when the caustic concentration, the total volume of leach solution, the temperature, and the leaching time are increased. ${ }^{8}$ It is important to note that the caustic concentration and leach time in Case 1 were higher than those in the typical ESW tests. In Case 2, the $\mathrm{NaOH}$ concentration, the solid/liquid ratio, the temperature, and leach time were increased significantly from the values in Case $1 .^{8}$ Table 7 shows the results of a second comparison, which involved only variations in the caustic concentration. ${ }^{8}$ An analysis of the results indicates that time and temperature play a large role in the increased leaching efficiency with this sludge. However, increases in the caustic concentration will only marginally improve the leach factors. Further support for these observations was obtained through simulations using equilibrium constants on sludge from Hanford tank S-101. ${ }^{17}$ The volume of $\mathrm{NaOH}$ that would be needed

Table 6. Examples of effect of increasing $\mathrm{NaOH}$ concentration, solution/sludge ratio, leach time, and leach temperature on S-104 sludge dissolution ${ }^{a}$

\begin{tabular}{|c|c|c|c|}
\hline Parameter & & Case 1 & Case 2 \\
\hline Sludge wt., $\mathrm{g}$ & & 1.49 & 1.10 \\
\hline $\mathrm{NaOH}$ conc., $M$ & & 3.99 & 6.33 \\
\hline $\mathrm{NaOH}$ vol., mL & & 15 & 30 \\
\hline Leach temp., ${ }^{\circ} \mathrm{C}$ & & 70 & 80 \\
\hline Leach time, $\mathrm{h}$ & & 21 & 126 \\
\hline \multirow{2}{*}{ Component } & \multirow{2}{*}{$\begin{array}{l}\text { Original sludge } \\
\text { conc. (mg/g) }\end{array}$} & \multicolumn{2}{|c|}{ Percent removed } \\
\hline & & Case 1 & Case 2 \\
\hline $\mathrm{Al}$ & 140 & 21 & 96 \\
\hline $\mathrm{Cr}$ & 3.1 & 98 & 99 \\
\hline $\mathbf{P}$ & 2.5 & 43 & 96 \\
\hline
\end{tabular}

${ }^{a}$ Reference 8. 
Table 7. Effect of $\mathrm{NaOH}$ concentration on caustic leaching of S-104

\begin{tabular}{ccc}
\hline & \multicolumn{2}{c}{ Percent removal } \\
\cline { 2 - 3 } Component & $3.99 \mathrm{MNaOH}$ & $6.33 \mathrm{MNaOH}$ \\
\hline $\mathrm{Al}$ & 21 & 27 \\
$\mathrm{Cr}$ & 98 & 97 \\
$\mathrm{P}$ & 43 & 49 \\
$\mathrm{Cs}$ & 97 & 99 \\
\hline
\end{tabular}

${ }^{a}$ Reference 8.

${ }^{b}$ Sludge weight $=1.5 \mathrm{~g} ; \mathrm{NaOH}$ volume $=15 \mathrm{~mL}$; leach temp. $=70^{\circ} \mathrm{C}$; leach time $=21 \mathrm{~h}$.

to treat a 1-g sample of S-101 sludge was calculated for the following temperatures and caustic concentrations: (1) $25^{\circ} \mathrm{C}$ and $1 M \mathrm{NaOH}(60 \mathrm{~mL}),(2) 70^{\circ} \mathrm{C}$ and $1 \mathrm{MNaOH}(20 \mathrm{~mL}),(3) 25^{\circ} \mathrm{C}$ and $3 \mathrm{M} \mathrm{NaOH}(17.3 \mathrm{~mL})$, and (4) $70^{\circ} \mathrm{C}$ and $3 \mathrm{M} \mathrm{NaOH}(5.7 \mathrm{~mL})$. It is interesting to note that as the temperature was increased, the number of $\mathrm{NaOH}$ moles per gram of sludge was decreased by a factor of 3 . However, an increase in the caustic concentration resulted in only a slight decrease in the number of $\mathrm{NaOH}$ moles per gram of S-101 sludge. It is important to remember that the caustic will eventually report to the LLW unless other treatment steps are taken to recycle this strean.

\subsection{Sodium Management}

During the initial evaluation of the ESW process, it was assumed in the reference flowsheet ${ }^{18}$ that only $10 \mathrm{Mkg}$ of sodium would be added during the ESW process. The total amount of sodium in the sludges in the Hanford single-shell tanks is approximately $8 \mathrm{Mkg}$. ${ }^{6,19}$ Therefore, the reference flowsheet assumes a $125 \%$ increase in the amount that is from the ESW process. However, all of the bench-scale tests have used much larger amounts of caustic than the reference flowsheet assumed, and the average increase in sodium was approximately $1300 \%$. In the case of sludge from Hanford tank S-101, the equilibrium calculations indicated that an increase of $114 \%$ in the amount of sodium would be needed to leach all of the aluminum, while the ESW test on the S-101 sludge increased the amount of sodium by $840 \%$. While the initial assumption appears to be reasonable based on the S-101 calculation, the $125 \%$ assumption must still be validated. Each $10 \%$ increase in the amount of caustic used in the ESW adds $\$ 64,000,000$ to the estimated cost to process and dispose of LLW, and a sodium increase of $1300 \%$ would more than double the amount of LLW. It must be reiterated that the ESW test conditions were chosen to perform the leaches quickly and efficiently; no implication is made that the full-scale operations would use these same conditions.

The large amount of caustic that may be required raises the issue of sodium management. DOE researchers have developed two technologies that can limit the amount of sodium to be immobilized as LLW. The first technology involves the clean salt process, which uses multiple fractional crystallizations of sodium nitrate to produce a decontaminatec. salt product from liquid waste or supernate, which is primarily sodium nitrate. Most of the radioactivity in the supernate is due to ${ }^{137} \mathrm{Cs}$. In a test with supernate from Hanford tank $\mathrm{AW}-101,{ }^{20}$ an average cesium decontumination factor (DF) of 21 was obtained for each stage, and a cumulative 
DF of $4 \times 10^{6}$ was obtained after five stages. No additional separation process was used except for filtration of the initial acidified waste feed to remove undissolved solids. However, before this technology can be used to reduce the amount of sodium to be immobilized, the Environmental Protection Agency must set limits that will permit free release of clean sodium nitrate. The second promising technology involves the use of electrochemical processes, which can generate clean sodium nitrate or sodium hydroxide. ${ }^{21,22}$

\subsection{Awareness of Solids Formation and Control}

The chemistry of sludge dissolution and leachate handling is complex. At the end of the ESW process, the remaining solids are considered to be $H L W$, while the potentially saturated solutions are defined as $L L W$ after cesium has been removed. However, solids will form in the solutions as they are permitted to cool or as they are mixed with other solutions. The leachates can result in the formation of crystalline solid precipitates and gels, which can cause significant processing problems. Therefore, a controlled precipitation may be required since the amount of caustic needed to prevent solids formation, as shown in Fig. $1,{ }^{23}$ is unacceptably large at $200 \mathrm{~L}$ of $3 \mathrm{MNaOH}$ per $\mathrm{kg}$ of aluminum. Clearly, the treatment of LLW liquid and LLW solids from the ESW process will be necessary.

ORNL DWG 96C-353R

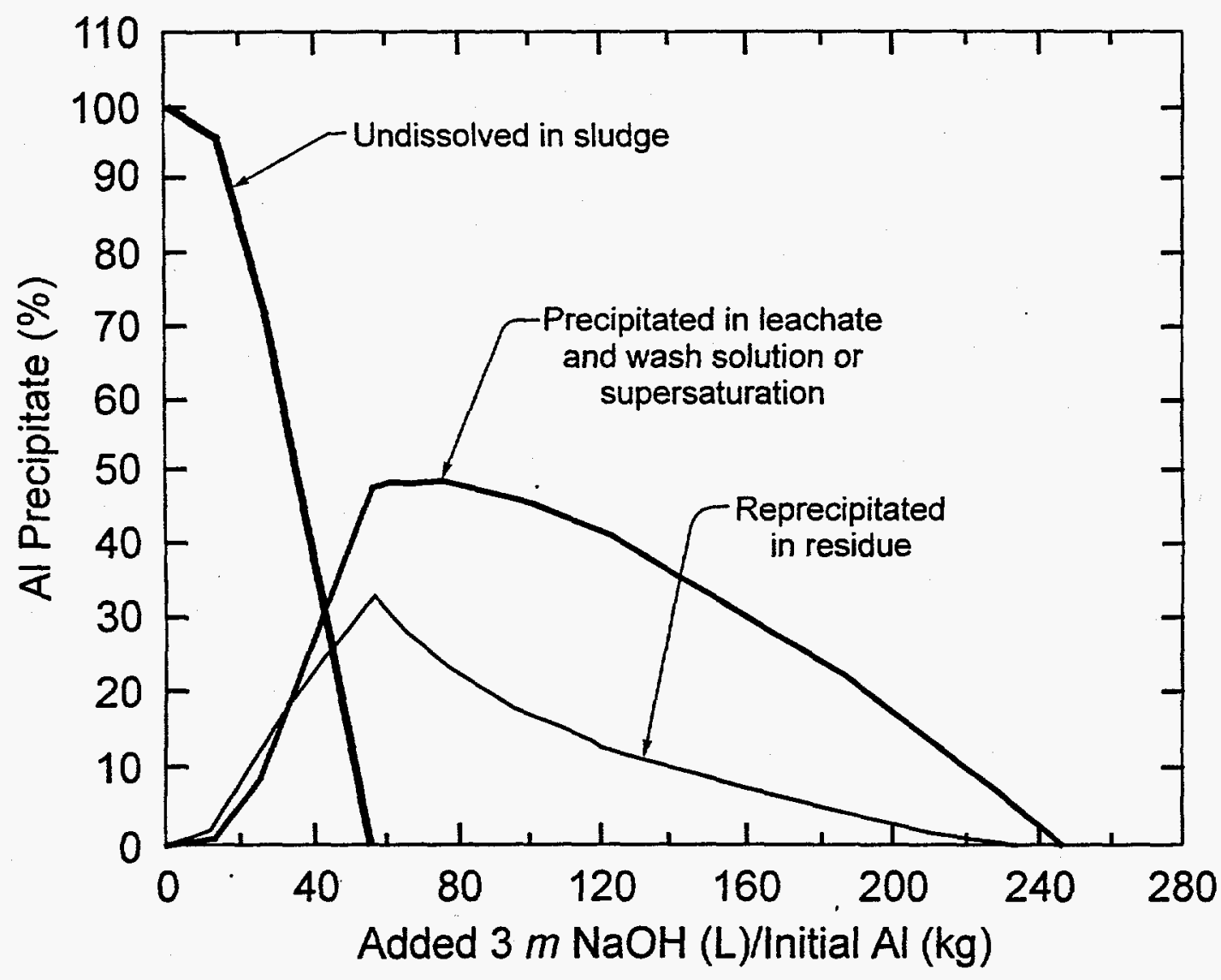

Fig. 1. Calculation of T-104 caustic leaching: $\mathrm{OH}^{-}$, initially $3 \mathrm{~m}$ at $75^{\circ} \mathrm{C}$; ambient temperature, $25^{\circ} \mathrm{C}$. 
Sludges and supernates containing phosphates offer additional challenges. Phosphate is typically present in the form of insoluble compounds and must be removed by the metathesis of water-insoluble metal phosphates to insoluble hydroxides and solubles phosphates. An example of this reaction is shown for iron phosphate in the following equation:

$$
\mathrm{FePO}_{4}(\mathrm{~s})+3 \mathrm{NaOH}(\mathrm{aq}) \rightarrow \mathrm{Fe}(\mathrm{OH})_{3}(\mathrm{~s})+\mathrm{Na}_{3} \mathrm{PO}_{4}(\mathrm{aq})
$$

However, additional problems are generated when an effort is made to solubilize phosphate, since phosphate solubility is very sensitive to temperature. After the leach at elevated temperatures, the phosphate may reprecipitate as a sticky gel as the liquid is cooled. The presence of fluoride in the tank can also greatly increase the complexity. Gels of natrophosphate, $\mathrm{Na}_{7}\left(\mathrm{PO}_{4}\right)_{2} \mathrm{~F} \cdot 19 \mathrm{H}_{2} \mathrm{O}$, have been observed in leached solutions of sludge from tank T-104. When this substance was wet, it resembled a gel; it was soft and stuck to the sample container walls. On drying, it appeared as a white mass.

Additional solids formations have been observed during sludge washing tests of sludge samples from tanks C-105, C-107, C-108, SX-113, B-202, and C-104. ${ }^{8}$ Upon processing and cooling, solids formed in 7 out of a total of 8 filtered sludge washing solutions (from different tanks) that were tested. With C-105 and C-107 tests, a clear gel-like material formed in the leachates. Wash solutions from the C-105 and C-107 tests also had some clear masses of sorbents. The lieachate from the C-108 test developed a mass of gel-like material, as well as some material that appeared to be more crystalline. The wash solutions from the C-108 test developed a small amount of filmy fibrous material. The filtered leachate from the SX-113 test generated a significant amount of particulate material that appeared to be semigelatinous when suspended. Scanning electron microscopy with energy-dispersive $\mathrm{X}$-ray analysis showed that these particles contained sodium and silicon. These particles could be any of a host of sodium silicates in the $\mathrm{NaOH}-\mathrm{SiO}_{2} \cdot \mathrm{H}_{2} \mathrm{O}$ system. The test with sludge from B-202 also produced particuliate material containing bismuth, a principal component of this sludge. ${ }^{24}$

Additional evidence of the problems with solids formation is the fact that several cross-site transfer lines are plugged at Hanford. This pluggage, which occurred following the transfer of hot, saturated solutions that were allowed to cool during transfer, has resulted in the abandonment of these transfer lines.

As a result of these observed problems, an alternative flowsheet ${ }^{23}$ has been proposed, based on the Bayer process in the aluminum industry. In this flowsheet, the sludge is leached at elevated temperatures and the aluminum, phosphate, and silicates in the leachate LLW stream are intentionally precipitated. This process may be aided by the addition of lime (to precipitate the anions) and flocculent, as shown in Fig. 2 . The resulting solids will be transported to the low-activity waste stream for immobilization. Although this refinement is not part of the current Hanford flowshtet, it is under consideration.

\section{CONCLUSIONS}

Numerous bench-scale tests have shown that the ESW will probably remove the required amounts of aluminum, phosphate, and chromiur.. Experimental and theoretical results have shown that leaching efficiency improves as time and temperaturs are increased while increases in the caustic concentration will only marginally improve the leach factors. However, it has also been assumed that the caustic added during the ESW process will generate only a small increase $(10 \mathrm{Mkg})$ in the amount of LLW. The bench-scale experiments were not designed to validate this assumption; rather, the test conditions were selected to maximize leaching in a short period. Theoretical calculations indicated that the amount of LLW from the ESW process appears to be reasonable. However, a more detailed study on the amount of LLW from the ESW process is needed. The findings should, at least, encourage remediation personnel to limit their use of caustic. If the LLW analysis indicates that sodium manajsement is critical, then a more comprehensive evaluation of the clean salt 
ORNL DWG 96C-69R4

6

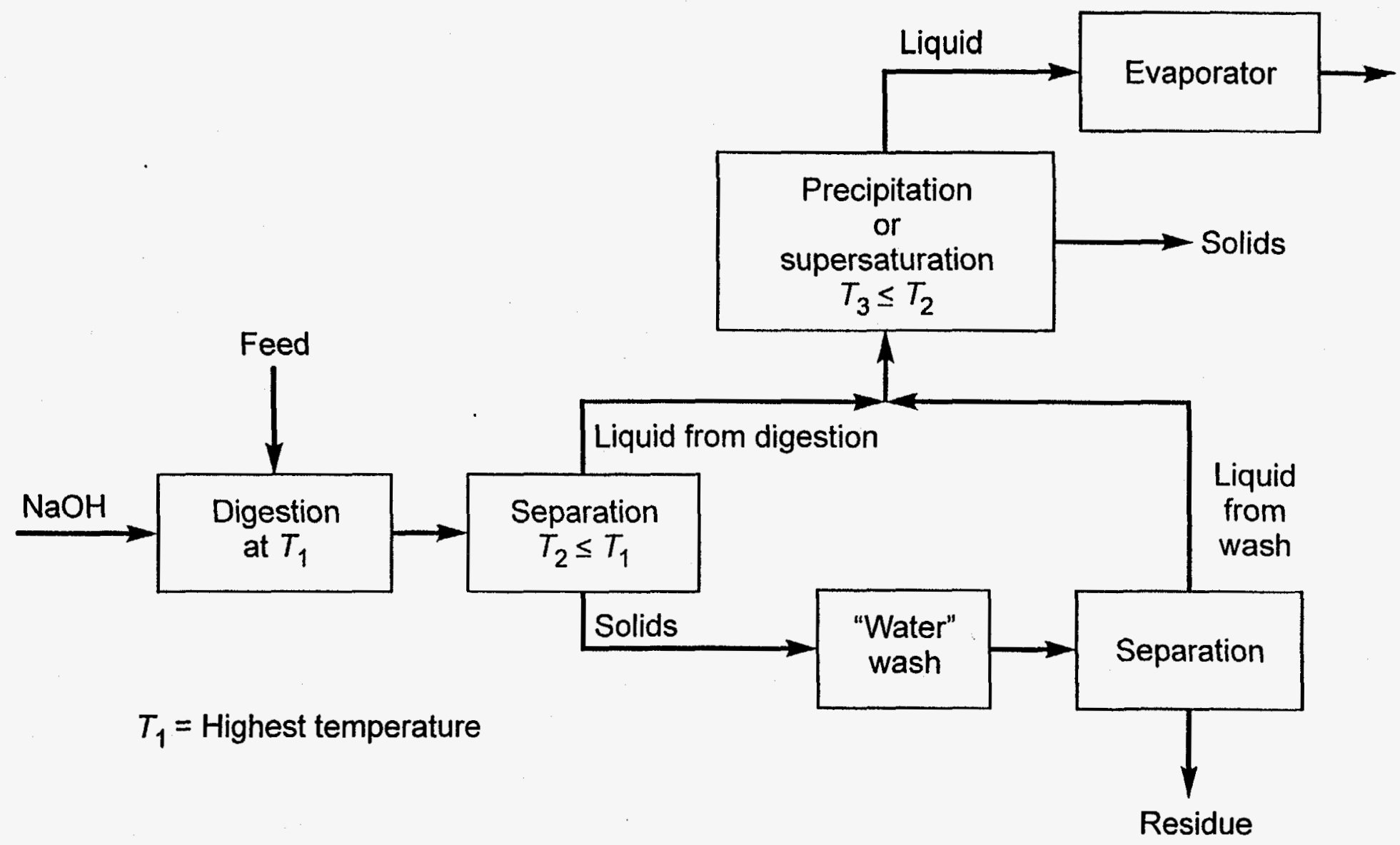

Fig. 2. Simplified diagram of enhanced sludge washing and the Bayer process. 
process or caustic recycle would be needed. Finally, experimental and theoretical studies have clearly demonstrated the need for the control of solids formation. Solids formation can be particularly difficult for wastes containing significant concentrations of phosphate. Solids can hamper downstream treatment steps such as cesium removal and, in the extreme cases, could plug lines. Methods to address these issues are needed.

\section{ACKNOWLEDGMENTS}

This work was funded by the U.S. Department of Energy through the Office of Science and Technology's Tanks Focus Area (TFA). The authors gratefully acknowledge the technical assistance from the following researchers: E. C. Beahm, J. L. Collins, B. Z. Egan, M. Hay, D. L. Herting, D. Hobbs, G. J. Lumetta, B. M. Rapko, B. B. Spencer, J. L. Swanson, and D. J. Temer. The authors would also like to thank the TFA management, which includes D. Geiser, T. L. Stewart, and T. M. Brouns.

\section{REFERENCES}

1. U.S. Department of Energy, Integrated Database Report-1995: U.S. Spent Nuclear Fuel and Radioactive Waste Inventories, Projections, and Characteristics, DOE/RW-0006, Rev. 12, 1996.

2. U.S. Department of Energy, Tanks Focus Area Annual Report, DOE/EM-0360, 1997.

3. R. D. Jensen, Enhanced Sludge Washing Evaluation Plan, WHC-EP-0805, Westinghouse Hanford Company, Richland, WA, . 994.

4. S. R. DeMuth, Estimating Heel Retrieval Costs for Underground Storage Tank Waste at Hanford, LA-UR-96-3038, Los Alamos National Laboratory, Los Alamos, NM, 1996.

5. International Atomic Energy Agency, Assessment and Comparison of Waste Management System Costs for Nuclear and Other Sources, Technical Reports Series No. 366, 1994.

6. N. G. Colton, Status Report: Pretreatment Chemistry Evaluation - Wash and Leach Factors for the Single Shell Tank Waste Inventory, PNNL-1 1290, Pacific Northwest National Laboraory, Richland, WA, 1997.

7. G. J. Lumetta, B. M. Rapko M. J. Wagner, J. Liu, and Y. L. Chen, Washing and Caustic Leaching of Hanford Tank Sludges: Results of FY 1996 Studies, PNNL-11278, Pacific Northwest National Laboratory, Richland, WA; 1996.

8. B. Z. Egan, B. B. Spencer, and C. W. Chase, Caustic Leaching of Sludges from Selected Hanford Tanks, ORNL/TM-13500, Oak Ridge National Laboratory, Oak Ridge, TN, 1998.

9. G. J. Lumetta and B. M. Rapko, Washing and Alkaline Leaching of Hanford Tank Sludges: A Status Report, PNL-10078, Pacific Northwest National Laboratory, Richland, WA, 1994. 
10. B. M. Rapko, G. J. Lumetta, and M. J. Wagner, Washing and Caustic Leaching of Hanford Tank Sludges: Results of FY 1995 Studies, PNL-10712, Pacific Northwest Laboratory, Richland, WA, 1995.

11. G. J. Lumetta, B. M. Rapko, M. J. Wagner, J. Liu, and Y. L. Chen, Washing and Caustic Leaching of Hanford Tank Sludge: Results of FY 1996 Studies, PNNL-11278, Rev. 1, Pacific Northwest National Laboratory, Richland, WA, 1996.

12. G. J. Lumetta, M. J. Wagner, F. V. Hoopes, and R. T. Steele, Washing and Caustic Leaching of Hanford Tank C-106 Sludge, PNNL-11381, Pacific Northwest National Laboratory, Richland, WA, 1996.

13. G. J. Lumetta, L. E. Burgeson, M. J. Wagner, J. Liu, and Y. L. Chen, Washing and Caustic Leaching of Hanford Tank Sludges: Results of FY 1997 Studies, PNNL-11636, Pacific Northwest National Laboratory, Richland, WA, 1997.

14. D. J. Temer and R. Villarreal, Sludge Washing and Alkaline Leaching Tests on Actual Hanford Tank Sludge: A Status Report, LAUR-95-2070, Los Alamos National Laboratory, Los Alamos, NM, 1995.

15. D. J. Temer and R. Villarreal, Sludge Washing and Alkaline Leaching Tests on Actual Hanford Tank Sludge: FY 1996 Results, LAUR-96-2839, Los Alamos National Laboratory, Los Alamos, NM, 1996.

16. D. J. Temer and R. Villarreal, Sludge Washing and Alkaline Leaching Tests on Actual Hanford Tank Sludge: FY 1997 Results, LAUR-97-2889, Los Alamos National Laboratory, Los Alamos, NM, 1997.

17. R. D. Hunt, J. L. Collins, and C. W. Chase, Water Washes and Caustic Leaches of Sludge from Hanford Tank S-101 and Water Washes of Sludge from Hanford Tank C-103, ORNL/TM-13655, Oak Ridge National Laboratory, Oak Ridge, TN, 1998.

18. R. M. Orme, TWRS Process Flowsheet, WHC-SD-WM-TJ-613, Westinghouse Hanford Company, Richland, WA, 1994.

19. J. G. Hill, G. S. Anderson, and B. C. Simpson, The Sort on Radioactive Waste Type Model: A Method to Sort Single-Shell Tanks into Characteristic Groups, PNL-9814, Pacific Northwest Laboratory, Richland, WA, 1995.

20. D. E. Kurath, K. P. Brooks, G. W. Hollenberg, G. W. Sutija, D. P. Landro, and T. Balagopol, "Caustic Recycle from High-Salt Nuclear Wastes Using a Ceramic-Membrane Salt-Splitting Process," paper presented at the Tenth Symposium on Separation Science and Technology for Energy Applications, Gatlinburg, TN, Oct. 20-24, 1997.

21. D. E. Kurath, G. W. Hollenberg, J. F. Jue, J. Smith, A. V. Virkar, S. Balagopol, and D. P. Sutija, "Salt Splitting Using Ceramic Membranes," paper presented at the Tenth Symposium on Separation Science and Technology for Energy Applications, Gatlinburg, TN, Oct. 20-24, 1997.

22. D. L. Herting, Clean Salt Process Final Report, WHC-EP-0915, Westinghouse Hanford Company, Richland, WA, 1996. 
23. E. C. Beahm, C. F. Webe:;, R. D. Hunt, and T. A. Dillow, "Solids Control in Sludge Treatment," paper presented at the Summer American Chemical Society Meeting, Las Vegas, NV, 1997.

24. C. F. Weber and E. C. Beabm, Chemical Modeling of Waste Sludges, ORNL/TM-13200, Oak Ridge National Laboratory, Oak Ridge, TN, 1996. 
ORNL/TM-13663

\section{INTERNAL DISTRIBUTION}

1. E. C. Beahm

2. J. L. Collins

3. A. G. Croff

4. R. D. Hunt

5. R. T. Jubin

6-20. C. P. McGinnis

21. L. E. McNeese
22. S. M. Robinson

23. B. B. Spencer

24. J. S. Watson

25-29. T. D. Welch

30. Central Research Library

31. ORNL Laboratory Records-RC

32-33. ORNL Laboratory Records-OSTI

\section{EXTERNAL DISTRIBUTION}

34. Jimmy Bell, 137 Bowspirit Lane, Kingston, TN 37763

35. Penny Colton, Pacific Northwest National Laboratory, Battelle Boulevard, P.O. Box 999, MS K8-93, Richland WA 99352

36. Zane Egan, 103 Lewis Lane, Oak Ridge, TN 37830

37. Randy Kirkbride, Numatec Hanford Corporation, P.O. Box 1300, MS H5-27, Richland, WA 99352

38. Louis Kovach, Hanford, P.O. Box 1970, K6-51, Richland WA 99352

39. Gregg Lumetta, Pacific Northwest National Laboratory, Battelle Boulevard, P.O. Box 999, MS P7-25, Richland WA 99352

40. Kristin Manke, Pacific Northwest National Laboratory, Battelle Boulevard, P.O. Box 999, MS K9-69, Richland WA 99352

41. Jacquie Noble-Dial, U.S. Department of Energy, Oak Ridge Operations Office, P.O. Box 2001, Oak Ridge, TN 37830-8620

42. Bryan Rapko, Pacific Northwest National Laboratory, Battelle Boulevard, P.O. Box 999, MS P7-25, Richland WA 99352

43. Wally Schultz, W2S Company, Inc., 5314 Arbustos Court, NE, Albuquerque, NM 87111

44. David Swanberg, SAIC, MS H0-50, 3250 Port of Benton Blvd., Richland, WA 99352

45. John Swanson, 1318 Cottonwood Drive, Richland, WA 99352

46. Don Temer, Los Alamos National Laboratory, NMT-1 CMR, MS G740, Los Alamos, NM 87545

47. Major Thompson, Westinghouse Savannah River Company, Building C-140, Room 773-A, Savannah River Technology Center, Aiken, SC 29808

48. George Vandegrift, Argonne National Laboratory, 9700 South Cass Avenue, Building 205, Argonne, IL 60439

49. Ray Wymer, 188-A Outer Drive, Oak Ridge, TN 37830

50-57. Tanks Focus Area Technical Team, c/o G. C. Notch, Pacific Northwest National Laboratory, Battelle Boulevard, P.O. Box 999, MSIN K9-69, Richland WA 99352 
58. Tanks Focus Area Field Lead, c/o J. A. Frey, U.S. Department of Energy, Richland, Operations Office, P.O. Box 550, MS K8-50, Richland, WA 99352

59. J. O. Honeyman, Lockheed Martin Hanford Corporation, P.O. Box 1500, MS G3-21, Richland, WA 99352

60. D. Geiser, Office of Technology System, 19901 Germantown Rd., 1183/Cloverleaf Bldg., Germantown, MD 20874-1290

61. Billie Mauss, Richland Operations Office, P.O. Box 550, MS K8-50, Richland, WA 99352

62. C. S. Louie, Richland Opierations, Office P.O. Box 550, MSIN B4-55, Richland, WA 99352

63. Steve Agnew, Los Alamos National Laboratory Chemical Science and Tech. Division Group CST-4, MS J586, TA-46 Bldg. 0218 Rm. 130, Los Alamos, NM 87545

64. W. Tamosaitis, P.O. Box 616, Bldg. 773-A, Room 231, Aiken, SC 29802

65. J. P. Morin, Savannah River Technology Center, 703-H Bldg., Aiken, SC 29808

66. L. M. Papouchado, Savainnah River Technology Center, P.O. Box 616, Aiken, SC 29802

67. Bryan Roy, Foster Wheeler, 111 Union Valley Road, Oak Ridge, TN 37830-8045 